\title{
Protective Effect of Nutmeg and Rosemary on Oxidative Stress in Hypercholesterolemic Rats
}

\author{
Naglaa H. M. Hassanen \\ Special Food and Nutrition Department, Food Technology Research Institute, Agriculture Research Center, Giza, Egypt
}

Email address:

naglaahassaneen@yahoo.com

To cite this article:

Naglaa H. M. Hassanen. Protective Effect of Nutmeg and Rosemary on Oxidative Stress in Hypercholesterolemic Rats. International Journal of Nutrition and Food Sciences. Vol. 4, No. 4, 2015, pp. 465-476. doi: 10.11648/j.ijnfs.20150404.18

\begin{abstract}
The present work was conducted to study the effect of nutmeg (Myristica fragrans) and rosemary (Rosmarinus officinalis) spices or their essential oils on the nutritional parameters of rats suffering from hypercholesterolemic. Fifty-four male rats weighting approximately 300 grams were divided into nine groups, each group containing six rats. Group H1 fed on basal diet as a control negative group. Group $\mathrm{H} 2$ fed on diets containing $15 \%$ of beef tallow instead of the fresh sunflower oil proportion and allowed added $1 \%$ of $\mathrm{H} 2 \mathrm{O} 2$ in the drinking water to increase the oxidative stress and the other groups $\mathrm{H} 4, \mathrm{H} 5$, H6, H7, H8 and $\mathrm{H} 9$ fed on the same diet used in group $\mathrm{H} 2$ and supplemented with different treatments nutmeg, rosemary and mixture powders groups H4, H5, H6 (2g / $100 \mathrm{~g}$ diet), respectively. Meanwhile, groups H7, H8 and H9 fed on the same diet used in group $\mathrm{H} 2$ and supplemented with different treatments nutmeg, rosemary and mixture essential oils $(0.6 \mathrm{gm} / 100 \mathrm{gm}$ fat), respectively. Group $\mathrm{H} 3$ fed on the same diet used in group $\mathrm{H} 2$ and supplemented with (drug) Lipitor Atorvastatin(20 $\mathrm{mg} / \mathrm{Kg} \mathrm{BW}$ rat/day by stomach tube). After 8 weeks the rats feeding with treatments and hypercholesterolemic diet rats significantly decreased levels of glucose. The treatment also resulted in a significant improvement in lipid profile, oxysterol levels, liver function, and kidney function. However, a significantly increment in the activities of superoxide dismutase (SOD), catalase (CAT), glutathione peroxidase (GSH-Px) and glutathione reduced (GSH) were observed in blood of hypercholesterolemic rats treated with nutmeg, rosemary powders or their essential oils. The treated groups showed a significant decrement in thiobarbituric acid reactive substances (MDA) in serum. Since the study of induction of the redox enzymes is considered to be a reliable marker for evaluating the antiperoxidative efficacy of the spices. Treatment with nutmeg, rosemary powders or their essential oils reduces the histopathological, heart, liver and kidney abnormalities associated with hypercholesterolemic.
\end{abstract}

Keywords: Nutmeg, Rosemary, Essential Oils, Oxysterol, Liver Function, Kidney Function, MDA, Histopathological

\section{Introduction}

Cardiovascular diseases (CVD) including coronary heart disease and stroke are the leading cause of mortality in both developed and developing countries, accounting for roughly $20 \%$ of all worldwide deaths per year [1]. Therefore, hypercholesterolemia and its associated CVD represent one of the greatest worldwide economic, social and medical challenges that we are facing now. The large majority of epidemiological studies have demonstrated that elevated plasma triglycerides and/or reduced plasma HDL-Ch concentrations are associated with increased cardiovascular risk [2]. An abnormal ratio of triglycerides to HDL-Ch indicates an atherogenic lipid profile and a risk for the development of coronary diseases. Changes in endothelial function play an important role in the pathophysiology of atherosclerosis and there is evidence suggesting that interventions to improve endothelial function may have an impact on the progression and the risk of cardiovascular events [3]. Reactive oxygen species (ROS), which include hydrogen peroxide and other chemical forms known as free radicals are produced as part of many normal and essential biological processes. These include the contraction of muscle, secretion of hormones, and the respiratory burst accompanying phagocytosis as part of the immune defense system. The production of ROS is both essential and detrimental to life. There is now evidence suggesting that ROS attack and damage key biomolecules, including lipid, 
protein and cellular damage, initiates several diseases including atherosclerosis, arthritis, diabetes, cancer agening and DNA mutation [4]. Oxidative stress in the cells or tissues refers to enhanced generation of ROS and depletion in the antioxidants defense system causing an imbalance between prooxidants and antioxidants [2]. Under normal conditions, antioxidant defense systems can remove reactive species through enzymatic (like superoxide dismutase and glutathione peroxidase) and non-enzymatic antioxidants [5]. However, in certain circumstances the endogenous defense system fails to protect the body against reactive radicals on its own. These results shown in oxidative stress, a condition in which the generation of highly reactive molecules such as reactive oxygen species (ROS) and reactive nitrogen species (RNS) when their elimination is inadequate [6]. Cholesterol is a monounsaturated lipid with a double bond on carbon-5. Therefore it is susceptible to oxidation in the presence of oxygen, free radicals mechanism leading to the formation of hydroperoxides and then a number of oxidation products, called oxysterols [7]. Many different oxysterols have been identified, and many probably remain to be identified. Oxysterol levels in the body can be increased through auto oxidation or normal enzymatic degradation of cholesterol, as a product of oxidative stress and through dietary intake [8]. Oxysterols that to be more polar than cholesterol may also be absorbed in intestinal track by a mechanism similar to that of cholesterol absorption [7]. Humans can absorb oxysterols from food into the blood stream. Oxysterols may enter the blood circulation with dietary cholesterol as a part of chylomicron structure. Oxysterols are also transported by low-density lipoproteins (LDL), and there is evidence that high-density lipoprotein (HDL) are also involved in transport of oxysterols from tissues to the liver. Oxysterols may be taken up from the plasma by tissues and organs many times more rapidly than cholesterol. In addition, oxysterols have been shown to exhibit cytotoxicity in a number of cell lines, including smooth muscle cells, fibroblasts and vascular endothelial cells [9].

It was the aim of this work to examine the nutritional and protective effect of nutmeg (Myristica fragrans) and rosemary (Rosmarinus officinalis.) on hypercholesterolemic rats for 60 days.

\section{Materials and Methods}

Nutmeg (Myristica fragrans) and Rosemary (Rosmarinus officinalis) spices were purchased from Pharmaceutical Science Laboratory, National Research Centre, Giza, Egypt. Lipitor Atorvastatin was purchased from pharmacy. Beef tallow was purchased from the local market.

Extraction of essential oils: The essential oils of nutmeg and rosemary were extracted by water distillation using a glass apparatus for 4 hours. The obtained volatile oil was dried over anhydrous sodium sulphate, and then holds in completely filled a glass bottle at $-20^{\circ} \mathrm{C}$ until use [10].

Animals: Fifty four male Wister rats, average weight of
$300 \mathrm{~g} \pm 0.5 \mathrm{~g}$. raised in the animal house of the Ophthalmology Research Institute, Giza , Egypt,, were used in the present study. The rats were kept in normal healthy laboratory condition; temperature was adjusted at $25 \pm 2{ }^{\circ} \mathrm{C}$ and 12 hour light - dark. Animals were adapted on free access of water, and fed for one week basal diet before the initiation standard of the experimental .The Composition of the basal diet $(\mathrm{g} / \mathrm{kg})$ : Casein, $21.7 \%$, fresh vegetable oil, $15 \%$, corn starch, $58.1 \%$; cholic acid $0.2 \%$, salt mixture, $4 \%$ and vitamin mixture, $1 \%$ according to $[11,12$ and 13 , respectively].

Experimental design: The 54 rats were equally divided into 9 groups of six rats and were kept in wire cages in an equal room temperature of $25^{\circ} \mathrm{C} \pm 2$ with normal healthy conditions maintained. Food consumption was monitored and the weekly weight gain was determined. The rats of (H1) we fed on basal diet and were considered a control negative group (normal control). The other eight groups were given $15 \%$ of beef tallow instead of the fresh sunflower oil proportion and allowed added $1 \%$ of $\mathrm{H} 2 \mathrm{O} 2$ in the drinking water to increase the oxidative stress. Group H2 fed on diets containing 15\% of beef tallow instead of the fresh sunflower oil proportion and allowed added $1 \%$ of $\mathrm{H} 2 \mathrm{O} 2$ in the drinking water to increase the oxidative stress .Seven groups were administrated Lipitor Atorvastatin $(20 \mathrm{mg} / \mathrm{Kg} \mathrm{BW}$ rat/day by stomach tube) (drug group, H3)[14],nutmeg powder (group, H4) (2g / 100 g diet), rosemary powder (rosemary group, H5) ( $2 \mathrm{~g} / 100 \mathrm{~g}$ diet), mixtures nutmeg and rosemary powder (mixtures, H6) (2g / $100 \mathrm{~g}$ diet), nutmeg essential oil (group, H7) (0.6gm / 100 gm fat), rosemary essential oil (rosemary group, H8) (0.6 gm / 100 gm fat) and mixtures (nutmeg and rosemary) essential oils (mixtures, H9) (0.6gm / $100 \mathrm{gm}$ fat).

Growth of rats: The gained weight was calculated by: the final weight - the initial body weight

Biochemical assay: when the 60 days was finished (the period of experimental), the blood samples were collected from the eye plexuses of the animals. Then they were put into a dry clean centrifuge glass tube without any coagulation to prepare serum. The samples were left for 15 minutes at normal of the temperature of room, after that the tubes were centrifuged for another 15 minutes at $300 \mathrm{rmp}$. From then until the time of analysis the clean supernatant serum was kept frozen at $-20{ }^{\circ} \mathrm{C}$. determination of serum glucose level was done by [15]. Methods of [16], [17], [18], [19],[20] and [21] described the determination the levels of Total cholesterol, high density lipoprotein, low density lipoprotein, VLDL- cholesterol, triglycerides and atherogenic index, respectively. Liver function: Alanine aminotransferase and aspartate aminotransferase activities were described methods of [22]. Alkaline phosphatase activity was measured at 405 $\mathrm{nm}$ of paranitrophenol from para-nitrophenylphosphate of the formation as a substance using the method of [23]. Kidney function: creatinine was measured using he method of [24], urea was measured using the method of [25] while uric acid was measured using the method of [26].The activity of lipid peroxidation level (Malondialdehyde, MDA) was determined in serum by the colorimetric method described by [27]. 
Glutathione reduced (GSH), glutathione peroxides $\left(\mathrm{GSH}-\mathrm{P}_{\mathrm{X}}\right)$ superoxide dismutase (SOD) and Catalase were measured calorimetrically in erythrocyte according to the method of [28, 29, 30 and 31, respectively].

Extraction of oxysterol from plasma: Oxysterols were extracted from plasma according to the method described by [32] as follow: $500 \mu \mathrm{l}$ plasma and $2 \mathrm{ml}$ of $1 \mathrm{M} \mathrm{KOH}$ in methanol containing $0.05 \%$ butylated hydroxyl toluene (BHT) (as antioxidant) were mixed. The tube was flushed with N2 and samples were allowed to saponify at room temperature over-night. To the saponified sample, $4 \mathrm{ml}$ of water were added and lipid was extracted twice with $3 \mathrm{ml}$ hexane. The lipid extract was dried under N2 and the residue was dissolved in $500 \mu \mathrm{l}$ acetonitril and put in small dark bottles until analysis using HPLC.

Oxysterols were determined by HPLC according to the method described by [33]. Oxysterols were identified by Hewlett Packard HP 1050 high performance liquid chromatography equipped with UV detector set at $210 \mathrm{~nm}$. The chromatograph was fitted with ODS hypersil column $(250 \times 4 \mathrm{~mm}, 5 \mu \mathrm{m})$, and the column heater was set at $35^{\circ} \mathrm{C}$. A mixture of acetonitril, methanol and water in a ratio of 46: 45: 9 , $(\mathrm{V} / \mathrm{V} / \mathrm{V})$ was used as a mobile phase at a flow rate of $0.7 \mathrm{ml} \mathrm{min}-1$.

Histopathological examination: At the end of the experiment samples from hearts, livers and kidney of the rats of all groups were collected and fixed in $10 \%$ neutral buffered formalin, the samples were dehydrated in alcohol, cleared in xylol and embedded in paraffin. $4 \mu$ thick Hematoxylene and eosin stained sections were prepared [34].

Statistical analysis: The obtained results were subjected to statistical analysis using the standard analysis of variance as outlined by [35].

\section{Results}

The current study was implemented to demonstrate the protective and nutritional impact of nutmegs, rosemary powders and their essential oils in experimental rats feed hypercholesterolemic diet, using one concentration of nutmegs, rosemary powders and their essential oils in male Wister rats for 2 months. The examined parameters were chemical components, food consumption, body weight gain, relative organs weight, some biochemical tests and histopathological examination of heart, liver and kidneys in normal and experimental rats. Their effects and constituents are recorded in tables.

Effect of nutmegs, rosemary powders and their essential oils on gain of body weight and weights of relative organ hypercholesterolemic rats: Effect of feeding on hypercholesterolemic diet for 60 successive days mixed with nutmegs, rosemary powders and their essential oils on body weight gain of rats and its results had been summarized in table (1) . Data presented in Table (1) show the initial body weights did not significantly differ among the groups and at the end of experiment, regardless of the diet variation, there was increased significantly differences among all the tested rat groups except in case of the (p. control) which was low significantly increased $(51.14 \%)$ in body weight gain comparing to non- hypercholesterolemic (N-Control). Meanwhile, nutmegs, rosemary powders at $(2 \mathrm{~g} / 100 \mathrm{~g}$ diet $)$ and their essential oils at $(0.6 \mathrm{gm} / 100 \mathrm{gm}$ fat $)$ with hypercholesterolemic diet increased in body weight gain comparing to hypercholesterolemic diet (P-Control).

On contrary, there were no significant differences were found in heart, liver and kidney on their relative weight $(\%)$ of rats except that rats feed on hypercholesterolemic diet (H2 and H3) groups table (1).

Table (1). Effect of nutmegs, rosemary powders or their essential oils on net gain and \% (liver, kidney and heart) organs in experimental of hypercholesterolemic rats.

\begin{tabular}{|c|c|c|c|c|c|c|}
\hline Treatments & Initial (g) & Final (g) & Net gain & Heart $\%$ & Liver\% & Kidney\% \\
\hline N. control H1 & $299.7^{\mathrm{a}} \pm 1.700$ & $317.6^{\mathrm{g}} \pm 2.625$ & $17.93^{\mathrm{g}} \pm 0.930$ & $0.25^{\mathrm{c}} \pm 0.050$ & $2.85^{\mathrm{d}} \pm 0.850$ & $0.53^{\mathrm{d}} \pm 0.130$ \\
\hline P. control H2 & $299.8^{\mathrm{a}} \pm 0.840$ & $308.6^{\mathrm{h}} \pm 3.590$ & $8.75^{\mathrm{h}} \pm 2.750$ & $0.43^{\mathrm{a}} \pm 0.130$ & $4.46^{\mathrm{a} \pm 0.460}$ & $0.95^{\mathrm{a}} \pm 0.350$ \\
\hline $\mathrm{H} 3$ & $299.9^{\mathrm{a}} \pm 1.880$ & $330.4^{\mathrm{f}} \pm 3.370$ & $30.49^{\bar{f}} \pm 1.490$ & $0.32^{\mathrm{b}} \pm 0.050$ & $3.92^{\mathrm{b}} \pm 0.420$ & $0.84^{\mathrm{ab}} \pm 0.090$ \\
\hline $\mathrm{H} 4$ & $299.6^{\mathrm{a}} \pm 1.650$ & $354.6^{\mathrm{e}} \pm 2.590$ & $55.06^{\mathrm{e}} \pm 0.963$ & $0.33^{\mathrm{b}} \pm 0.080$ & $3.67^{\mathrm{bc}} \pm 0.670$ & $0.73^{\mathrm{bc}} \pm 0.230$ \\
\hline H5 & $299.5^{\mathrm{a}} \pm 0.470$ & $356.5^{\mathrm{e}} \pm 2.414$ & $56.98^{\mathrm{e}} \pm 2.014$ & $0.32^{\mathrm{b}} \pm 0.080$ & $3.59^{\mathrm{c}} \pm 0.590$ & $0.70^{\mathrm{bc}} \pm 0.300$ \\
\hline H6 & $299.5^{\mathrm{a}} \pm 2.550$ & $386.4^{\mathrm{c}} \pm 1.390$ & $86.84^{\mathrm{c}} \pm 1.160$ & $0.30^{\mathrm{bc}} \pm 0.080$ & $3.43^{\mathrm{c}} \pm 0.430$ & $0.68^{\mathrm{cd}} \pm 0.180$ \\
\hline H7 & $300.4^{a} \pm 2.360$ & $383.4^{\mathrm{d}} \pm 2.380$ & $83.02^{\mathrm{d}} \pm 0.020$ & $0.31^{\mathrm{b}} \pm 0.060$ & $3.52^{\mathrm{c}} \pm 0.520$ & $0.71^{\mathrm{bc}} \pm 0.110$ \\
\hline $\mathrm{H} 8$ & $300.1^{\mathrm{a}} \pm 1.100$ & $390.7^{b} \pm 5.690$ & $90.59^{\mathrm{b}} \pm 4.590$ & $0.33^{\mathrm{b}} \pm 0.080$ & $3.47^{\mathrm{c}} \pm 0.270$ & $0.69^{\mathrm{bc}} \pm 0.140$ \\
\hline H9 & $299.6^{\mathrm{a}} \pm 1.650$ & $398.5^{\mathrm{a}} \pm 2.500$ & $98.85^{\mathrm{a}} \pm 0.850$ & $0.31^{\mathrm{b}} \pm 0.090$ & $3.56^{\mathrm{c}} \pm 0.360$ & $0.70^{\mathrm{bc}} \pm 0.120$ \\
\hline \multicolumn{7}{|l|}{ LSD } \\
\hline & 1.173 & 2.219 & 2.903 & 0.05474 & 0.03048 & 0.1548 \\
\hline
\end{tabular}

Means, within the same column, followed by the same letter are not significantly different at $<0.05$.

Means are followed by the corresponding standard deviation.

Effect of nutmegs, rosemary powders and their essential oils on serum glucose levels and lipid profile levels of hypercholesterolemic rats: Table (2) display the level of serum glucose in normal and experimental animals. The data revealed a significant increased elevation (131.07\%) in blood glucose in (P. control) rats compared to $(\mathrm{N}$. control) normal rats. Supplemented provision of nutmegs, rosemary, mixtures powders at ( $2 \mathrm{~g} / 100 \mathrm{~g}$ diet) and nutmegs, rosemary, mixtures essential oils at $(0.6 \mathrm{gm} / 100 \mathrm{gm}$ fat $)$ with hypercholesterolemic diet significantly decreased (24.04, $24.61,24.77$ and $35.06,37.85$ and $38.37 \%$, respectively) the level of blood glucose compared to (P. control) control group. 
On the other hand, there were no significant variances in glucose among rats feed on nutmegs, rosemary essential oils at (0.6 gm / $100 \mathrm{gm}$ fat) groups throughout the feeding periods (60 days).The hypercholesterolemic diet significantly increased elevation $(135.19 ; 453.96 ; 256.61$ and $256.69 \%$, respectively) in serum total cholesterol; low- density lipoprotein- cholesterol; triglyceride and very low- density lipoprotein- cholesterol in (P. control) rats compared to $(\mathrm{N}$. control) normal rats. While, HDL- cholesterol was significantly declined $(61.23 \%)$ in (P. control) rats compared to (N. control) normal rats as shown in Table (2). Administration of the tested nutmegs, rosemary powders at ( $2 \mathrm{~g} / 100 \mathrm{~g}$ diet $)$ and their essential oils at $(0.6 \mathrm{gm} / 100 \mathrm{gm}$ fat) improved or returned these values to the normal ones. On contrary, there were non-significant differences in serum total cholesterol, HDL- cholesterol ,low density lipoproteincholesterol, triglyceride and very low density lipoproteincholesterol in among rats feed on nutmegs, rosemary powders at $(2 \mathrm{~g} / 100 \mathrm{~g}$ diet $)$ or their essential oils at ( $0.6 \mathrm{gm} /$ $100 \mathrm{gm}$ fat) groups throughout the feeding periods (60 days).

Table (2). Effect of nutmegs, rosemary powders or their essential oils on glucose, total cholesterol, HDL-C, LDL-C, VLVL-C triglycerides and Atherogenic index levels in experimental of hypercholesterolemic rats.

\begin{tabular}{|c|c|c|c|c|c|c|c|}
\hline Treatments & $\begin{array}{l}\text { Glucose } \\
\text { (mg/dl) }\end{array}$ & $\begin{array}{l}\text { TC } \\
(\mathrm{mg} / \mathrm{dl})\end{array}$ & $\begin{array}{l}\text { HDL-C } \\
(\mathrm{mg} / \mathrm{dl})\end{array}$ & $\begin{array}{l}\text { LDL-C } \\
(\mathrm{mg} / \mathrm{dl})\end{array}$ & $\begin{array}{l}\text { VLDL-C } \\
(\mathrm{mg} / \mathrm{dl})\end{array}$ & $\begin{array}{l}\text { T.G } \\
\text { (mg/dl) }\end{array}$ & $\begin{array}{l}\text { Atherogenic } \\
\text { index }\end{array}$ \\
\hline N. control H1 & $83.35^{\mathrm{f}} \pm 1.35$ & $84.40^{g} \pm 2.40$ & $47.20^{a}+2.20$ & $24.37^{\mathrm{h}} \pm 0.37$ & $12.63^{\mathrm{e}} \pm 0.230$ & $63.15^{\mathrm{e}} \pm 1.15$ & $0.78^{\mathrm{d}} \pm 0.025$ \\
\hline P. control H2 & $192.60^{a} \pm 2.64$ & $198.50^{\mathrm{a}} \pm 1.50$ & $18.30^{\mathrm{f}} \pm 1.30$ & $135.0^{\mathrm{a}} \pm 0.50$ & $45.05^{a} \pm 0.450$ & $225.20^{\mathrm{a}} \pm 2.24$ & $9.87^{\mathrm{a}} \pm 0.656$ \\
\hline $\mathrm{H} 3$ & $127.80^{\mathrm{d}} \pm 1.85$ & $117.60^{d} \pm 1.60$ & $40.89^{c} \pm 1.89$ & $50.00^{\mathrm{d}} \pm 0.50$ & $25.74^{\mathrm{c}} \pm 0.135$ & $128.70^{\mathrm{c}} \pm 0.68$ & $1.857^{\mathrm{c}} \pm 0.070$ \\
\hline $\mathrm{H} 4$ & $146.30^{b} \pm 2.29$ & $126.20^{b} \pm 2.18$ & $36.46^{\mathrm{e}} \pm 2.46$ & $62.00^{\mathrm{b}} \pm 1.00$ & $27.26^{\mathrm{b}} \pm 0.26$ & $136.30^{\mathrm{b}} \pm 1.29$ & $2.457^{b} \pm 0.13$ \\
\hline H5 & $145.20^{\mathrm{bc}} \pm 0.17$ & $125.40^{\mathrm{bc}} \pm 0.40$ & $37.25^{\mathrm{de}} \pm 0.25$ & $60.60^{c} \pm 0.60$ & $27.08^{b} \pm 0.29$ & $135.42^{\mathrm{b}} \pm 1.42$ & $2.353^{b} \pm 0.01$ \\
\hline H6 & $144.90^{c} \pm 0.95$ & $125.00^{\mathrm{c}} \pm 0.50$ & $37.88^{d} \pm 0.88$ & $59.87^{c} \pm 0.42$ & $27.08^{b} \pm 0.08$ & $135.38^{\mathrm{b}} \pm 0.38$ & $2.300^{\mathrm{b}} \pm 0.07$ \\
\hline $\mathrm{H} 7$ & $119.30^{\mathrm{e}} \pm 1.28$ & $101.20^{\mathrm{e}} \pm 1.17$ & $42.29^{\mathrm{bc}} \pm 1.29$ & $36.47^{\mathrm{e}} \pm 0.75$ & $22.19^{\mathrm{d}} \pm 0.59$ & $111.00^{\mathrm{d}} \pm 2.96$ & $1.387^{\mathrm{d}} \pm 0.05$ \\
\hline H8 & $119.70^{\mathrm{e}} \pm 1.73$ & $99.75^{\mathrm{f}} \pm 1.75$ & $42.50^{\mathrm{b}} \pm 2.50$ & $35.00^{\mathrm{f}} \pm 1.00$ & $22.07^{\mathrm{d}} \pm 0.47$ & $110.30^{\mathrm{d}} \underline{-} 2.35$ & $1.343^{\mathrm{d}} \pm 0.045$ \\
\hline H9 & $118.70^{\mathrm{e}} \pm 1.65$ & $99.29^{\mathrm{f}} \pm 1.29$ & $43.67^{\mathrm{b}} \pm 0.67$ & $33.47^{g} \pm 0.31$ & $21.95^{\mathrm{d}} \pm 0.33$ & $109.80^{\mathrm{d}} \pm 1.65$ & $1.270^{\mathrm{d}} \pm 0.00$ \\
\hline \multicolumn{8}{|l|}{ LSD } \\
\hline & 1.261 & 1.170 & 1.406 & 1.014 & 0.2844 & 1.433 & 0.3589 \\
\hline
\end{tabular}

Means, within the same column, followed by the same letter are not significantly different at $<0.05$.

Means are followed by the corresponding standard deviation.

Effect of nutmegs, rosemary powders or their essential oils on cholesterol oxidation products (COPs) in plasma of hypercholesterolemic rats: It was clear from table (3) hypercholesterolemic diet produced significant adverse effects on oxysterol of the rats, which is evidenced by a significant increase elevation in 25 - hydroxycholestero , 7 $\beta$ hydroxycholesterol, 7-ketocholesterol and 5,6- $\beta$ - Epoxycholesterol in (P. control) compared to (N. control) normal .Treatment of hypercholesterolemic rats with nutmegs, rosemary powders and their essential oils exhibited improvement oxysterol compared to ( $\mathrm{P}$. control) rats. Meanwhile, there were non-significant differences in 25hydroxycholestero, 7 $\beta$-hydroxycholesterol, 7-ketocholesterol and 5,6- $\beta$ - Epoxy-cholesterol in among rats feed on with nutmegs, rosemary essential oils and mixtures at $(0.6 \mathrm{gm} /$ $100 \mathrm{gm}$ fat) groups throughout the feeding periods (60 days).

Table (3). Effect of nutmegs, rosemary powders or their essential oils on cholesterol oxidation products (COPs) in plasma in experimental of hypercholesterolemic rats.

\begin{tabular}{|c|c|c|c|c|}
\hline Treatments & 25-hydroxycholesterol ( $\mu \mathrm{g} / \mathrm{ml})$ & 7ß-hydroxycholesterol $(\mu \mathrm{g} / \mathrm{ml})$ & 7-ketocholesterol $(\mu \mathrm{g} / \mathrm{ml})$ & $\begin{array}{l}5,6-\beta \text { - Epoxy-cholesterol } \\
(\mu \mathrm{g} / \mathrm{ml})\end{array}$ \\
\hline N. control H1 & $48.26^{\mathrm{e}}+1.26$ & $00.00^{\mathrm{e}} \pm 0.00$ & $0.00^{\mathrm{d}} \pm 0.00$ & $287.3^{\mathrm{f}}+2.290$ \\
\hline P. control H2 & $568.3^{\mathrm{a}} \pm 1.29$ & $86.37^{\mathrm{a}} \pm 1.37$ & $52.46^{\mathrm{a}} \pm 1.46$ & $878.1^{\mathrm{a}} \pm 2.13$ \\
\hline $\mathrm{H} 3$ & $226.9^{\mathrm{c}}+0.89$ & $29.53^{\mathrm{c}} \pm 0.53$ & $34.17^{\mathrm{b}} \pm 0.17$ & $390.6^{\mathrm{d}} \pm 0.60$ \\
\hline H4 & $248.6^{\mathrm{b}} \pm 0.65$ & $34.22^{\mathrm{b}}+0.22$ & $35.29^{\mathrm{b}}+0.29$ & $394.8^{\mathrm{b}}+0.82$ \\
\hline H5 & $248.2^{\mathrm{b}} \pm 2.16$ & $33.56^{\mathrm{b}} \pm 0.56$ & $34.82^{\mathrm{b}} \pm 0.82$ & $393.7^{\mathrm{bc}} \pm 3.71$ \\
\hline H6 & $247.3^{\mathrm{b}} \pm 1.29$ & $33.12^{\mathrm{b}} \pm 1.12$ & $34.76^{\mathrm{b}} \pm 2.76$ & $392.6^{c} \pm 2.65$ \\
\hline $\mathrm{H} 8$ & $163.4^{\mathrm{d}} \pm 3.39$ & $20.45^{\mathrm{d}} \pm 3.45$ & $14.88^{\mathrm{c}}+2.88$ & $319.9^{\mathrm{e}} \pm 0.85$ \\
\hline H9 & $164.1^{\mathrm{d}} \pm 0.12$ & $19.38^{\mathrm{d}} \pm 3.38$ & $13.65^{c} \pm 1.65$ & $319.2^{\mathrm{e}} \pm 2.16$ \\
\hline \multicolumn{5}{|l|}{ LSD } \\
\hline & 1.650 & 2.236 & 1.908 & 1.887 \\
\hline
\end{tabular}

Means, within the same column, followed by the same letter are not significantly different at $<0.05$.

Means are followed by the corresponding standard deviation.

Effect of nutmegs, rosemary powders and their essential oils on liver functions of hypercholesterolemic rats: Administration of hypercholesterolemic diet produced significant adverse effects on the liver functions of the rats, which is evidenced by a significant increase elevation
(187.31 , 85.94; $153.16,97.36$ and $97.69,47.40 \%$, respectively) in the actions of ALT; AST and ALP enzymes in (P. control) and (drug) compared to (N. control) normal .Treatment of hypercholesterolemic rats with nutmegs, rosemary essential oils at (0.6 gm / $100 \mathrm{gm}$ fat) exhibited 
improvement in the actions of ALT, AST and ALP enzymes compared to ( $\mathrm{P}$. control) rats. On the other hand, there were non- significant variances in the actions of ALT, AST and
ALP enzymes in among rats feed on nutmegs, rosemary at (0.6 gm / $100 \mathrm{gm} \mathrm{fat)} \mathrm{groups} \mathrm{throughout} \mathrm{the} \mathrm{feeding} \mathrm{periods}$ (60 days) Table (4).

Table (4). Effect of nutmegs, rosemary powders or their essential oils on liver function and kidney function levels in experimental of hypercholesterolemic rats.

\begin{tabular}{|c|c|c|c|c|c|c|}
\hline \multirow{2}{*}{ Treatments } & \multicolumn{3}{|l|}{ Liver function } & \multicolumn{3}{|l|}{ Kidney function } \\
\hline & $\operatorname{ALT}(\mathbf{U} / \mathbf{L})$ & $\operatorname{AST}(\mathbf{U} / \mathrm{L})$ & $\operatorname{ALP}(\mathbf{U} / \mathbf{L})$ & Creatinine(mg/dl) & Urea(mg/dl) & Uric $\operatorname{acid}(\mathrm{mg} / \mathrm{dl})$ \\
\hline N. control H1 & $23.25^{\mathrm{g}} \pm 1.25$ & $29.57^{\mathrm{e}} \pm 2.57$ & $75.17^{\mathrm{f}} \pm 1.17$ & $0.470^{f} \pm 0.02$ & $20.19^{\mathrm{e}} \pm 0.19$ & $1.480^{\mathrm{g}} \pm 0.28$ \\
\hline P. control H2 & $66.80^{\mathrm{a}} \pm 1.80$ & $74.86^{\mathrm{a}} \pm 1.86$ & $148.60^{\mathrm{a}} \pm 2.60$ & $1.450^{\mathrm{a}} \pm 0.05$ & $38.28^{\mathrm{a}} \pm 1.28$ & $5.950^{\mathrm{a}} \pm 0.15$ \\
\hline $\mathrm{H} 3$ & $43.11^{\mathrm{b}} \pm 1.11$ & $58.36^{\mathrm{b}} \pm 2.36$ & $110.80^{\mathrm{b}} \pm 3.85$ & $1.100^{\mathrm{b}} \pm 0.10$ & $33.65^{\mathrm{b}} \pm 1.65$ & $5.370^{\mathrm{b}} \pm 0.37$ \\
\hline $\mathrm{H} 4$ & $39.74^{c} \pm 1.74$ & $42.89^{c} \pm 0.89$ & $96.94^{\mathrm{c}} \pm 0.94$ & $0.890^{\mathrm{c}} \pm 0.04$ & $29.47^{c} \pm 0.47$ & $4.880^{c} \pm 0.58$ \\
\hline H5 & $39.80^{c} \pm 0.80$ & $42.45^{c} \pm 0.45$ & $96.69^{c} \pm 0.69$ & $0.900^{\mathrm{c}} \pm 0.05$ & $29.43^{c} \pm 0.43$ & $4.750^{c} \pm 0.25$ \\
\hline H6 & $39.88^{\mathrm{d}} \pm 0.88$ & $42.64^{\mathrm{c}} \pm 2.64$ & $96.22^{\mathrm{cd}}+1.22$ & $0.850^{c} \pm 0.05$ & $28.84^{\mathrm{c}} \pm 0.84$ & $4.680^{\mathrm{c}} \pm 0.48$ \\
\hline H8 & $35.74^{\mathrm{ef}} \pm 1.74$ & $40.10^{\mathrm{d}} \pm 1.10$ & $94.45^{\mathrm{de}} \pm 1.45$ & $0.620^{\mathrm{e}} \pm 0.04$ & $26.00^{\mathrm{d}} \pm 1.50$ & $3.380^{\mathrm{de}} \pm 0.38$ \\
\hline H9 & $35.00^{\mathrm{f}} \pm 0.50$ & $39.65^{d} \pm 0.65$ & $94.00^{\mathrm{e}} \pm 0.50$ & $0.650^{\mathrm{de}} \pm 0.50$ & $25.90^{\mathrm{d}} \pm 1.90$ & $2.850^{f} \pm 0.35$ \\
\hline \multicolumn{7}{|l|}{ LSD } \\
\hline & 0.8082 & 1.456 & 1.841 & 0.05474 & 1.034 & 0.2508 \\
\hline
\end{tabular}

Means, within the same column, followed by the same letter are not significantly different at $<0.05$.

Means are followed by the corresponding standard deviation.

Effect of nutmegs, rosemary powders and their essential oils on kidney functions of hypercholesterolemic rats: It was clear from table (4) hypercholesterolemic diet produced significant adverse effects on the kidney functions of the rats, which is evidenced by a significant increase elevation ( 208.51, 134.04; 89.60, 66.67 and 302.02, $262.84 \%$, respectively) in creatinine ; urea and uric in (P. control) and group drug compared to (N. control) normal .Treatment of hypercholesterolemic rats with nutmegs, rosemary essential oils at (0.6 gm / $100 \mathrm{gm}$ fat) exhibited improvement in kidney functions compared to ( $\mathrm{P}$. control) rats. Meanwhile, there were non- significant differences in creatinine, urea and uric in among rats feed on nutmegs, rosemary at (0.6 gm / $100 \mathrm{gm}$ fat) groups throughout the feeding periods (60 days).

Effect of nutmegs, rosemary powders and their essential oils on malonaldehyde, enzymatic antioxidants and nonenzymatic antioxidants activity in experimental of hypercholesterolemic rats: Table (5) show the activity levels of malonaldehyde (MDA) in serum, enzymatic antioxidants,
(SOD), Catalase, (GSH-Px) and non- enzymatic antioxidants (GSH) in blood, respectively, in normal and experimental rat groups. The activities of serum maloaldehyde (MDA) activity was significantly increased (432.69\%, respectively) in (P. control) hypercholesterolemic compared to (N. control) normal. .While the activities of blood enzymatic antioxidants SOD, Catalase, (GSH-Px) and non- enzymatic antioxidants (GSH) were significantly decreased $(77.54,54.11,58.87$ and $67.75 \%$, respectively) in (P. control) compared to (N. control) normal. Supplemented of the experimental hypercholesterolemic rat groups with nutmegs, rosemary at (0.6 gm / $100 \mathrm{gm}$ fat) decreased the levels of malonaldehyde (MDA) and increased activities of enzymatic antioxidant, SOD, Catalase, GSH-Px and non-enzymatic antioxidants (GSH). On contrary, there were non-significant differences in MDA, SOD, Catalase, (GSH-Px) and non- enzymatic antioxidants $(\mathrm{GSH})$ in among rats feed on nutmegs, rosemary at (0.6 gm / 100 gm fat) groups throughout the feeding periods (60 days).

Table (5). Effect of nutmegs, rosemary powders or their essential oils on serum (MDA) and erythrocytes (SOD, Catalase, GSH and GSH-Px) levels in experimental of hypercholesterolemic rats.

\begin{tabular}{|c|c|c|c|c|c|}
\hline Treatments & $\operatorname{SOD}(\mathrm{U} / \mathrm{ml})$ & Catalase $(\mathrm{U} / \mathrm{ml})$ & GSH-Px(U/ml) & GSH(mg/dl) & MDA(nmol/ml) \\
\hline N. control H1 & $276.8^{a} \pm 1.75$ & $177.5^{\mathrm{a}} \pm 2.50$ & $168.7^{\mathrm{a}} \pm 2.73$ & $36.25^{\mathrm{a}} \pm 1.25$ & $4.650^{\mathrm{g}}+0.65$ \\
\hline P. control H2 & $62.17^{\mathrm{g}} \pm 1.17$ & $81.45^{\mathrm{g}} \pm 0.45$ & $69.38^{\mathrm{h}} \pm 1.38$ & $11.69^{\mathrm{g}} \pm 1.69$ & $24.77^{\mathrm{a}} \pm 1.77$ \\
\hline $\mathrm{H} 3$ & $195.6^{\mathrm{f}} \pm 2.63$ & $142.4^{\mathrm{f}} \pm 1.39$ & $131.3^{\mathrm{g}} \pm 0.88$ & $28.88^{\mathrm{f}} \pm 1.27$ & $9.95^{\mathrm{b}} \pm 0.95$ \\
\hline H5 & $213.7^{\mathrm{d}}+3.66$ & $150.2^{\mathrm{d}} \pm 2.20$ & $145.2^{\mathrm{e}} \pm 2.19$ & $31.95^{\mathrm{e}}+1.95$ & $8.75^{\mathrm{cd}}+0.65$ \\
\hline H6 & $214.9^{\mathrm{d}} \pm 2.87$ & $151.2^{\mathrm{d}} \pm 1.17$ & $148.2^{\mathrm{d}} \pm 2.22$ & $32.62^{\text {de }} \pm 0.62$ & $8.24^{\mathrm{de}} \pm 0.24$ \\
\hline $\mathrm{H} 7$ & $237.2^{\mathrm{c}} \pm 1.19$ & $166.9^{c} \pm 0.85$ & $153.3^{\mathrm{c}} \pm 1.34$ & $33.29^{\mathrm{cd}} \pm 2.29$ & $7.95^{\mathrm{def}} \pm 0.45$ \\
\hline H9 & $241.7^{\mathrm{b}} \pm 1.73$ & $169.2^{\mathrm{b}} \pm 2.21$ & $156.7^{\mathrm{b}} \pm 0.68$ & $34.36^{\mathrm{b}} \pm 1.36$ & $7.17^{\mathrm{f}} \pm 0.17$ \\
\hline \multicolumn{6}{|l|}{ LSD } \\
\hline & 1.437 & 1.194 & 1.067 & 0.9637 & 0.9528 \\
\hline
\end{tabular}

Means, within the same column, followed by the same letter are not significantly different at $<0.05$.

Means are followed by the corresponding standard deviation.

Pathological effects of different organs: Figure (1) show the microscopic examination of the heart of the experimental rat groups. (N. control) untreated rat group showed apparent normal cardiac muscle fibers with no histopathological changes slide (1). Meanwhile, heart of rat from group (P. control) H 2 showed intramuscular oedema, myolysis of 
cardiac myocytes associated with intramuscular oedema and few inflammatory cells infiltration between cardiac myocytes (slide 2, 3 and 4). However, heart of rat from group drug (H 3) showed intramuscular edema slide (5). While, heart of rat from all groups ( $\mathrm{H} \mathrm{4,} \mathrm{H} \mathrm{5,} \mathrm{H} \mathrm{6,} \mathrm{H} \mathrm{7,} \mathrm{H} 8$ and H 9) showed no changes with apparent normal heart (slide 6).

Meanwhile, Figure (2) show the microscopic examination of the liver of the experimental rat groups. (N. control) H 1 , untreated rat group showed a normal histological appearance of hepatic lobule slide (1). Meantime, liver of rat from group (P. control) H 2 showed Kupffer cell laden with hemosiderin pigment, hyperplasia of epithelial lining bile duct and cholangitis slide (2, 3 and 4). However, liver of rat from group drug (H 3 ) showed kupffer cells activation slide (5), In addition, liver of rat from groups $(\mathrm{H} 4, \mathrm{H} 5, \mathrm{H} 6, \mathrm{H} 7, \mathrm{H} 8$ and $\mathrm{H}$ 9) showed no changes with apparent normal hepatocytes slide (6).

Moreover, Figure (3) show the microscopic estimation of the kidney of the tested rat groups. (N. control), untreated rat group revealed a normal histological structure of renal parenchyma slide (1). Meanwhile, kidney of rat from group ( P. control) H 2 showed congestion of renal blood vessel, congestion of renal blood vessel and atrophy of glomerular tuft and vacuolation of epithelial lining renal tubules slide (2, 3 and 4). However, kidney of rat from group drug ( $\mathrm{H} \mathrm{3})$ showed atrophy of glomerular tufts slide (5). While, kidney of rat from groups $(\mathrm{H} \mathrm{4,} \mathrm{H} \mathrm{5,} \mathrm{H} \mathrm{6,} \mathrm{H} \mathrm{7,} \mathrm{H} 8$ and $\mathrm{H} \mathrm{9)} \mathrm{showed} \mathrm{no}$ changes with apparent normal kidney slide (6).

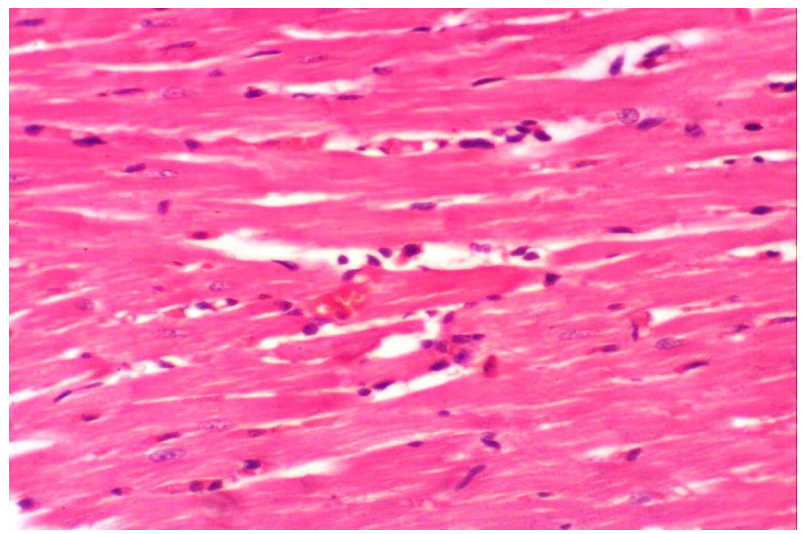

Slide (1): Control group

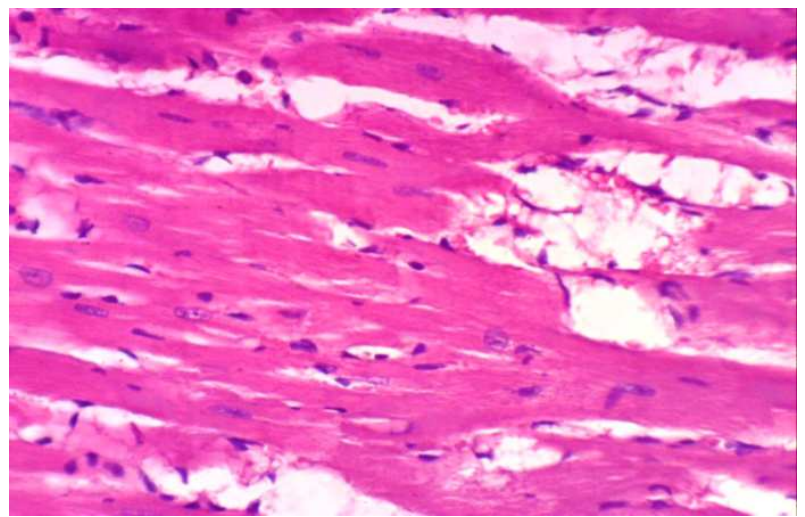

Slide (2): P. control group

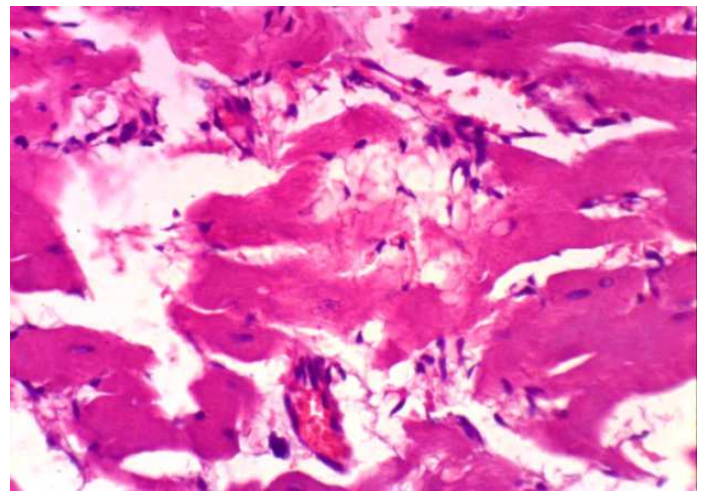

Slide (3): P.control group

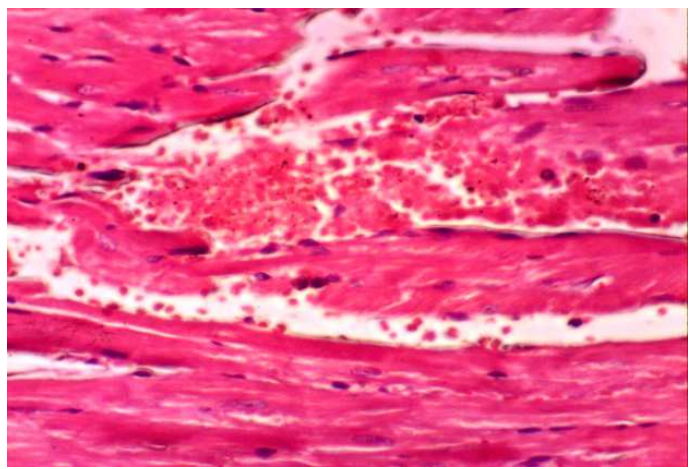

Slide (4): P.control group

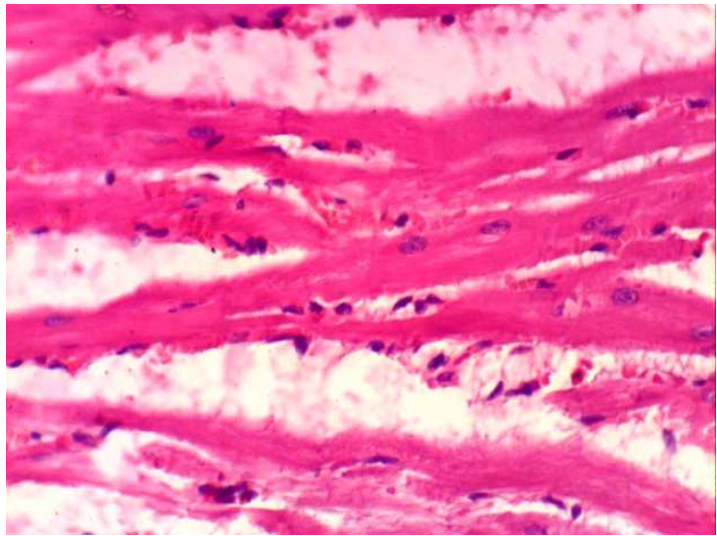

Slide (5): Drug group

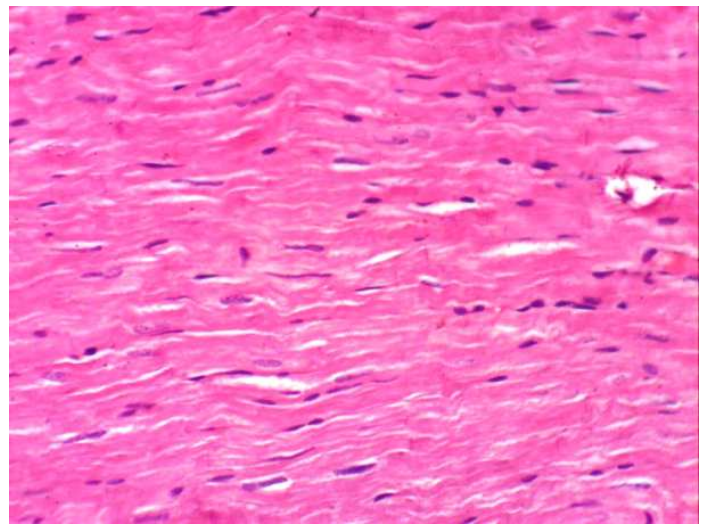

Slide (6): (H4 ,H5,H6, H7, H8and H9 groups)

Figure (1). Histopathological changes in tissue sections of heart. 


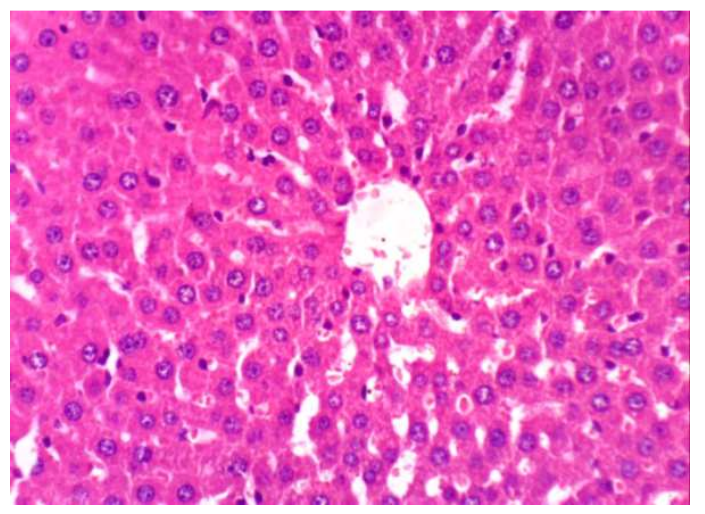

Slide (1): Control group

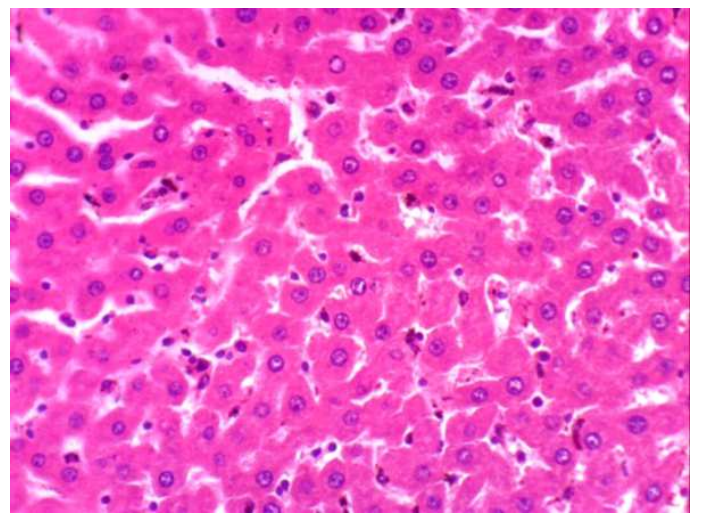

Slide (2): P.control group

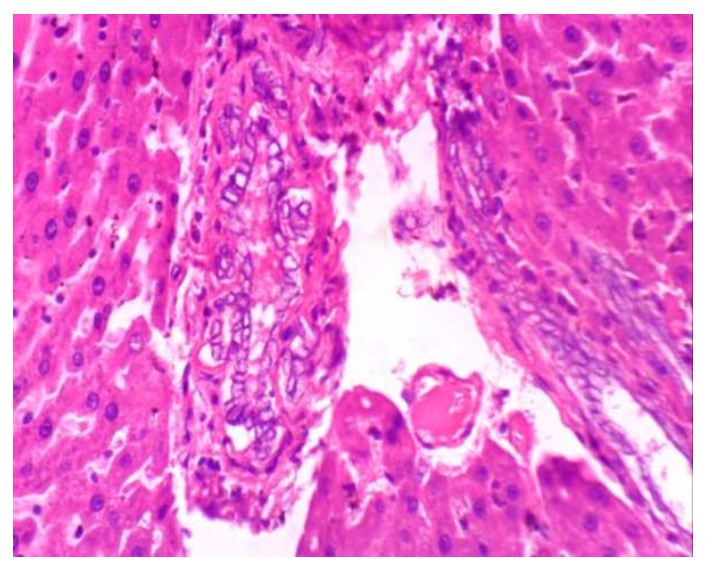

Slide (3): P.control group

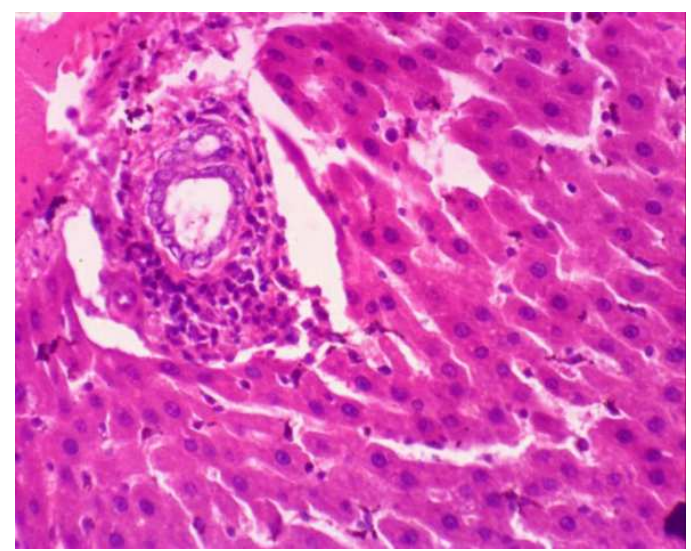

Slide (4): P.control group

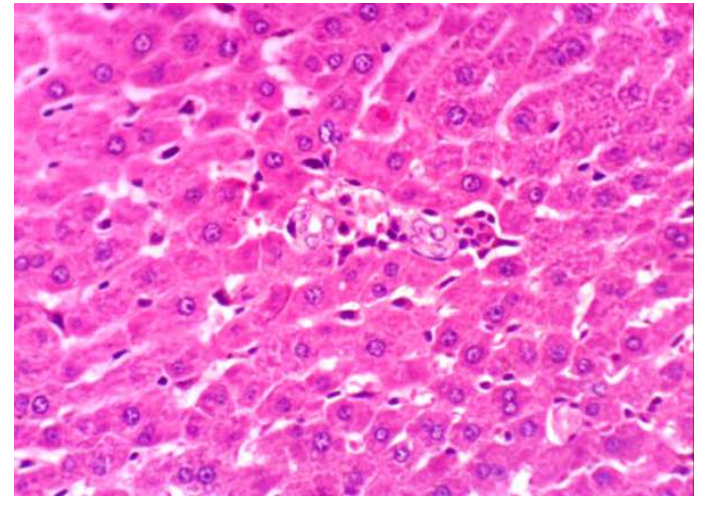

Slide (5): Drug group

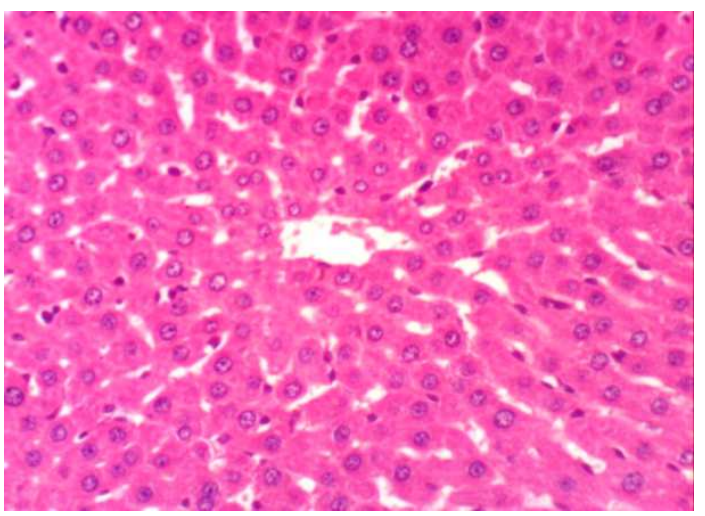

Slide (6): (H4 ,H5,H6, H7, H8and H9 groups)

Figure (2). Histopathological changes in tissue sections of liver.

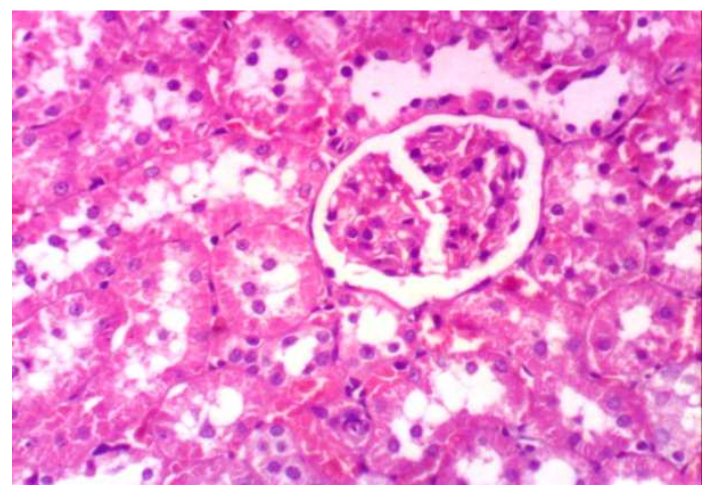

Slide (1): Control group

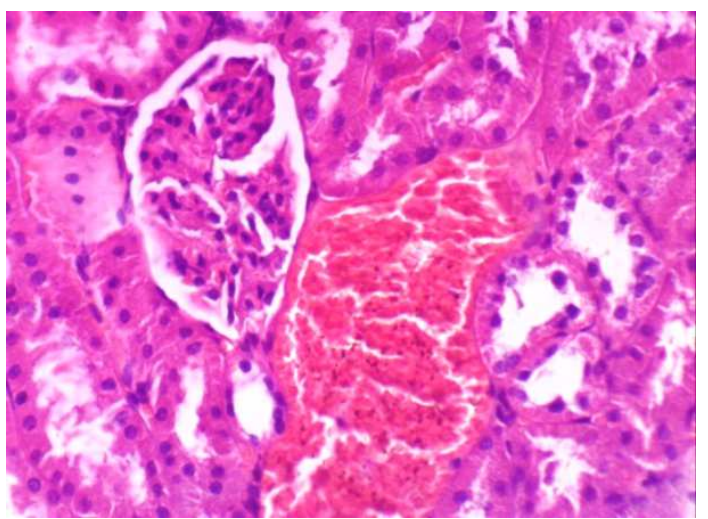

Slide (2): P.control group 


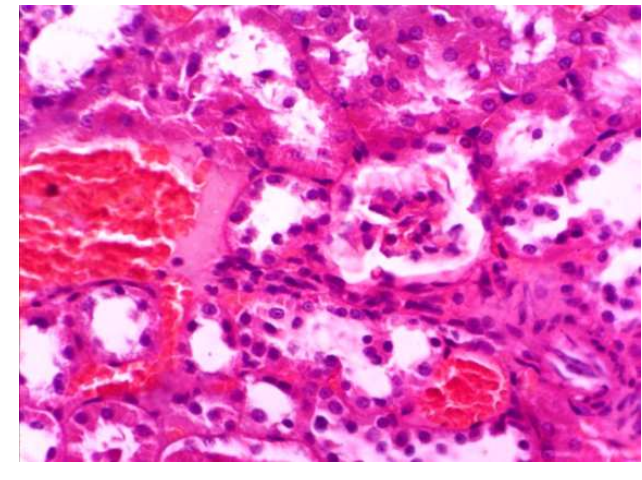

Slide (3): P.control group

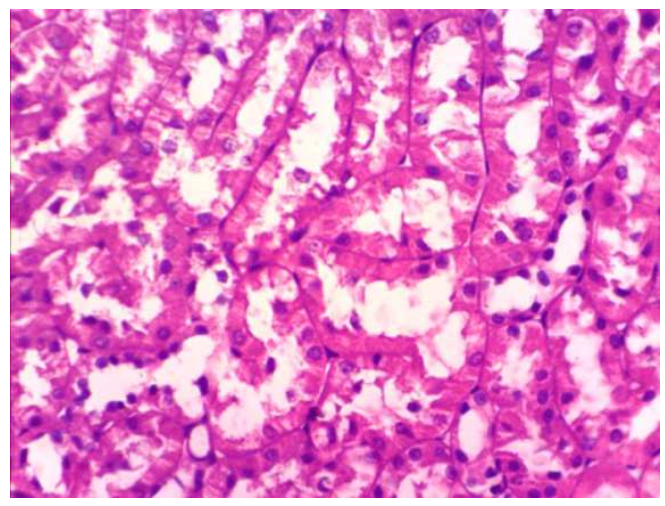

Slide (4): P.control group

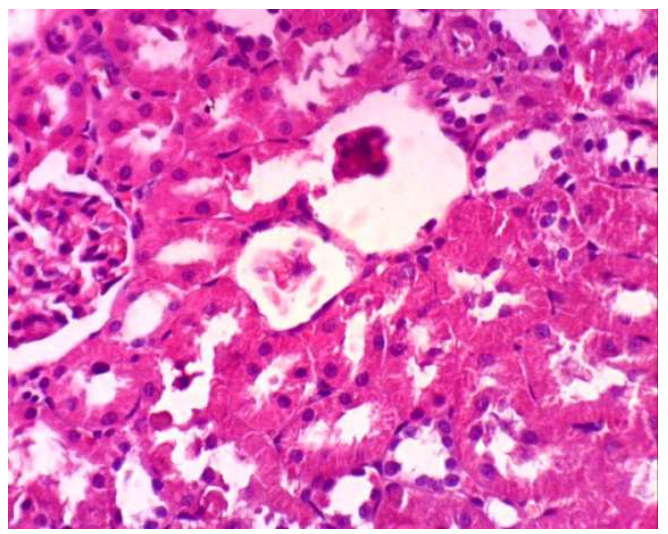

Slide (5): Drug group

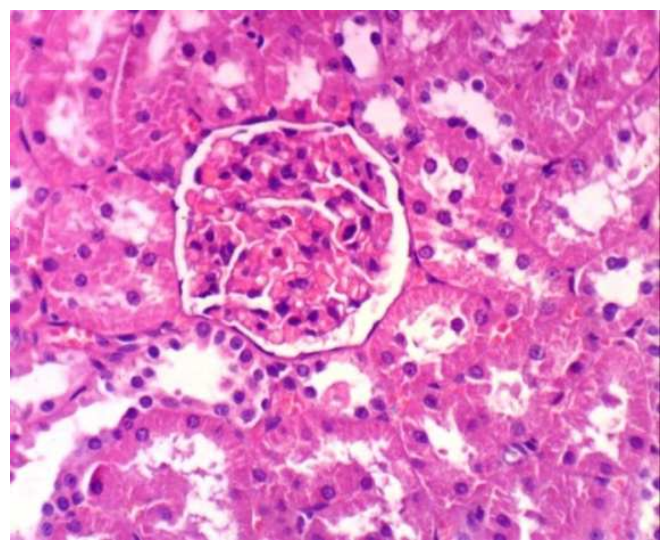

Slide (6): (H4 ,H5,H6 , H7, H8 and H9 groups)

Figure (3). Histopathological changes in tissue sections of kidney.

\section{Discussion}

Hypercholesterolemia plays an important role in atherosclerosis and related cardiovascular diseases (CVD). A high-cholesterol dietary habit is known to play an important role in the induction of chronic diseases such as hypercholesterolemia and hepatic abnormalities [36]. Nutmegs, rosemary powders or their essential oils have known to be preferable, beneficial and various activities The current study was implemented to demonstrate the protective and nutritional impact of nutmegs, rosemary powders or their essential oils in experimental hypercholesterolemic rats. The balance between antioxidant defense capacity and oxidative stress determine the capability of humans and animals to oxidative damage .The aging and pathology of many diseases caused by oxidative stress [37].

Effect of nutmegs, rosemary powders or their essential oils on intake of food and gain of body weight in hypercholesterolemic rats: Hypercholesterolemic diet for 60 successive days was increasing the weight gains and feed intake significantly this agreement [38]. The present results revealed that hypercholesterolemic diet significantly reduce food intake, compared to standard diet. These results may be attributed to higher caloric content of hypercholesterolemic diet compared to standard diet. High fat diet in the present study was responsible for increasing satiety and total calories. This result agreed with [39] which explained that high fat diet induce hypercholesterolemic, leads to lower ingestion by the animals and induces malnutrition. The beneficial effect of antioxidant administration against hypercholesterolemic poisoning with respect to body weight observed in the present study confirms previous results obtained by [40] who concluded that feeding rats with antioxidants could play an important role as a prophylactic against the toxic effects of high fat.

The relation between organs weight (liver and heart) and body weight might be based on fat accumulation in liver and heart cells. When organ weight was compared with final body weight, fat increased the hepatosomatic index causes liver damage [41] reported that higher ingestion of potentially toxic components by the rat fed high fat lead to higher hepatosomatic index. These results were confirmed by histopathological examination (fatty changes of hepatocytes and granularity of the sarcoplasm focal cardiac myocytes), accordance with [39], and the accumulation of intracellular lipid in cardiomyocytes in response to cholesterol diet [42]. Meanwhile, there was no difference in relative organs weight in rats feed on hypercholesterolemic diet with nutmegs, rosemary powders or their essential oils. While rats feed on high fat (H2 and $\mathrm{H} 3)$ showed increased in relative organs weight (heart, liver and kidney). The obtained data are agreements with [43] which reported that relative organs weight were significantly increased after rats feed on high fat.

Effect of nutmegs, rosemary powders or their essential oils on glucose levels and lipid profile levels in experimental hypercholesterolemic rats : The present results revealed that was non- significant in concentrations of serum glucose of 
rats given nutmegs, rosemary and mixtures essential oils for 60 days while serum glucose significantly high in hypercholesterolemic rats (P-Control) agreement with [44].

The concentration of (TC) and (LDL-C) were significantly influenced by the dietary hypercholesterolemic in all groups. Rats hypercholesterolemic diet (P-control) had higher concentrations of (TC) in serum than those fed on (N- control) and all groups. Rats fed on diets with nutmegs, rosemary spices or their essential oils had lower concentrations of (TC) and (LDL-C) in serum than those fed on hypercholesterolemic diets (P-control). Also, none significant change was observed between natural antioxidant in all groups. These results agree with that [45] .Dietary (P-control) increase oxidative stress and the presence of oxidized LDLcholesterol and other lipoproteins. Oxidation converts LDLcholesterol to a form that is rapidly taken up and degraded by macrophages and increased degradation of unoxidized LDLcholesterol. Antioxidants are inhibiting metabolism of LDLcholesterol and reduce toxicity of oxidized LDL-cholesterol. Oxidized lipoproteins may lead to development of atherosclerosis [46].

The increase in HDL-C may be a consequence of protection mechanism against the oxidative stress caused by the diet containing hypercholesterolemic and a mechanism to avoid oxidative changes in other lipoprotein such as LDL [47].

Serum high density lipoprotein cholesterol (HDL - C): as mention in Table (2) that the rats fed on natural antioxidant groups had lower in the concentrations of (HDL -C) compared with the group (N. control) rats. Meanwhile, hypercholesterolemic groups (P-control) had reduction in the concentrations of serum high density lipoprotein cholesterol (HDL - C) compared to all groups. [48] found that antioxidant rich foods increased the response to the oxidative damage in the pathogenesis of many diseases and increased HDL-C. Serum triglyceride (TG) and very low density lipoprotein cholesterol (VLDL - C): The concentration of (TG), (VLDL - C) were studied, as shown in table (2). These data indicate that, in rats fed on hypercholesterolemic diet (Pcontrol), the concentration of (TG) and (VLDL - C) increased significantly. Meanwhile, the other groups (H3, H4, H5, H6, H7, H8 and H9) fed on hypercholesterolemic diet and supplemented with different of antioxidants had lower value compared with group (P-control). These results are in agreement with [1].

Effect of nutmegs, rosemary powders or their essential oils on cholesterol oxidation products (COPs) of hypercholesterolemic rats: In the present study, rats exposed to $\mathrm{H} 2 \mathrm{O} 2$ generated much more oxysterols (Positive control). These oxysterols produced through free radical-mediated cholesterol peroxidation, can serve as molecular indicator of chain peroxidation damage in the cell membrane [33]. COPs are associated with the initiation and progression of major chronic diseases including atherosclerosis, neurodegenerative processes, diabetes, kidney failure, ethanol intoxication and influence membrane stability and cell death by altering membrane properties such as fluidity and permeability [49].
Increased COPs levels (mainly 7-KC and 7 $\beta$-HC) have been reported in disease states where oxidative stress was increased, such as diabetes mellitus or familial combined hyperlipidemia. In addition, significantly higher concentrations of COPs were found in the blood of diabetic and hypercholesterolemic patients than in the blood of control subjects [50]. [51] found that the levels of plasma 7 $\beta$ $\mathrm{HC}, 27-\mathrm{HC}$ and $7-\mathrm{KC}$, as well as other oxidative markers, were elevated in patients with Parkinson's disease. The use of COPs as biomarkers could improve the early diagnosis of diseases in which oxidative stress appears to be involved, such as neurodegenerative diseases, diabetes, and obesity.

Effect of nutmegs, rosemary powders or their essential oils on liver functions of hypercholesterolemic rats: Liver function could be detected the state of liver. Uses of Liver Function Tests (LFTS) to check liver impairment, evaluate the development of diseases, and monitor the impact of hepatotoxic drugs and necrosis in the liver of animals. Serum aminotransferases and alkaline phosphatase, bilirubin and albumin also the prothrombin time included in (LFTS) [52]. The Concentration of intracellular hepatic enzymes that have leaked into the circulation measured by alanine aminotransferase (ALT) and aspartate aminotrasferase (AST) .Moreover, normal functioning of live indicated by normal levels of ALT and AST, indicators of liver function. When the enzymes leak from the liver cytosol into the blood stream that lead to higher level of ALP in serum [53], which is indicative of hepatotoxic of hypercholesterolemic rats. Also one of the advantages of administration of some spices to hypercholesterolemic rats was a reduction in ALP activity to its regular levels. High levels of ALP in serum indicate liver damage. In the present study, the decrease in ALP activity in hypercholesterolemic rats given spices shows that presented liver damage, as a result of metabolic changes such as administration of toxin, liver cirrhosis, hepatitis, and cancer of the liver, the serum ALT, AST and ALP was increased [54].Thus, they can be used as markers to estimate the extent of liver damage. In this concern, it was reported that oxidative stress mediates many of the effects caused by oxidized fats [55].The formation of reactive oxygen species (ROS) may increase the dietary oxidized fats and may cause an increased damage of proteins in the liver by enhancing lipid per oxidation of the cell membrane and increasing the generation of (ROS) which can lead to calcium homeostasis disturbances, increase membrane fluidity and cell death. On the other hand, [1] found that, nutmegs, rosemary spices and their essential oils contain substances that delay the rate of oxidation by directing the breakdown of peroxides into stable substances that do not promote further oxidation or by sweeping free radicals away. Histopathological study of liver showed kuffer cells activation, vacuolar degeneration of hepatocytes and fatty degeneration of centro-lobular hepatocytes in the liver of hypercholesterolemic rats. Damaged membranes were recovered by the treatment with spices through enhancing antioxidants' status and decreasing lipid peroxidation [44].

Effect of nutmegs, rosemary powders or their essential oils 
on kidney functions of hypercholesterolemic rats: Creatine metabolism by muscles produce creatinine as a major waste product of the process. In kidneys, it's filtered by the glomerulus and excreted by the tubules besides freecreatinine appears in the blood serum [56], urea and uric acid are the principal waste products of protein catabolism. They synthesized in the liver from ammonia produced as a result of the deamination of amino acids. The rate of production is accelerated by a high protein diet or by increased endogenous catabolism due to starvation or tissue damage [57]. Kidney function tests help to determine if the kidney are performing their task adequately. Our study, demonstrated that hypercholesterolemic rats had a renal modification such as accumulation of fat in cells, increased kidney weight gain, glomerular sclerosis and inflammatory infiltrates, along with elevated levels of blood glucose, reinforce the idea that glycosylation of proteins, increased the release of proinflammatory cytokines, oxidative stress, and the accumulation of lipid peroxidation products may be caused kidney damage [58]. In normal pathological states nutmegs, rosemary essential oils have been described as anti-oxidants that remove free radicals for cell protection [59]. Deterioration of the tissues and enlarged the kidneys of hypercholesterolemic rats [60]. Congestion of renal blood vessels, expansion of the tubules lining cells, vacuolation of epithelial lining renal tubule and endothelial lining glomerular tufts and in obese rats were shown by histopathological studies of kidneys, which may be associated with membrane damage as a result of elevated fatty acid composition and oxidative stress, reserved these changes to near optimal was shown with spices therapy, which can be related to the reduction of membrane damage as evidenced by enhanced anti-oxidants status [60].

Effect of nutmegs, rosemary powders or their essential oils on malonaldehyde, enzymatic antioxidants and nonenzymatic antioxidants activity in experimental of hypercholesterolemic rats: A stressful condition leads to the excessive production of free radicals which results in oxidative stress an imbalance in the oxidant per antioxidant system. Generation of free radicals is an integral feature of normal cellular functions in contrast to excessive generation and/or inadequate removal of free radical results in destructive and irreversible damage to the cell [37]. Under normal conditions, there is a natural defense system provided by several enzymes such as Superoxide Dismutase (SOD), Catalase (CAT), Glutathione Peroxidase (GSH-Px) and nonenzymatic antioxidants Glutathione reduced (GSH) which performs a vital role for detoxification of free radicals. The use of antioxidant rich food or antioxidant food supplements became immensely popular since many diseases have been associated with oxidative stress [61].Therefore the objective of this research was to investigate the effect of nutmegs, rosemary essential oils on antioxidant enzyme in rats hypercholesterolemic diet after 8 weeks of treatment. Nutmegs and rosemary contains characteristic polyphenolic compounds .The most important function of these compounds can either stimulate endogenous antioxidant defense systems or scavenge reactive species [44].

In the present study concluded that the concentration of lipid peroxidation is successful indicator to the increment of free radicals in the hypercholesterolemic. Consequently, administration of nutmeg (Myristica fragrans) and rosemary (Rosmarinus officinalis) significantly declined the levels of lipid peroxidation, reducing the formation of cholesterol oxidization products (COPs) and thus prevent tissue damage.

\section{References}

[1] Doha A. M.; Thanaa E. H. and Sahar Y. A., (2010). Reduction in hypercholesterolemia and risk of cardiovascular diseases by mixtures of plant food extracts: a study on plasma lipid profile, oxidative stress and testosterone in rats. Grasas Y Aceites, 61 (4), 378-389.

[2] Rahman T., Ismail H., Towhidul I. M. M., Hossain U. S., (2012). Oxidative stress and human health. Advances in Bioscience and Biotechnology, 3, 997-1019.

[3] Thorand B, Baumert J, Chambless L, Meisinger C, Kobb H, Doring A,(2006). For the MONICA/KORA study group. Elevated markers of endothelial dysfunction predict type 2 diabetes mellitus in middle-aged men and women from the general population. Arterioscler Thromb. Vasc. Biol. 26, 398405 .

[4] Thanan R., Shinji O. , Yusuke H. , Shiho O. , Ning M. ,Somchai P. , Puangrat Y. , Shosuke K. and Mariko M., (2015). Oxidative Stress and Its Significant Roles in Neurodegenerative Diseases and Cancer. Int. J. Mol. Sci., 16, 193-217.

[5] Gill S. S. and Tuteja N.,(2010). Reactive oxygen species and antioxidant machinery in abiotic stress tolerance in crop plants. Plant Physiology and Biochemistry, 48 , 909- 930.

[6] Anh N. L., ( 2015). Lipoprotein-Associated Oxidative Stress: A New Twist to the Postprandial Hypothesis. Int. J. Mol. Sci., $16,401-419$.

[7] Shazamawati Z.H. ;A.R. Alina; A. Siti Mashitoh and M.J. Thema Juhana , (2013). Cholesterol Oxidation Products Analysis in Meat and Poultry. Middle-East J. Sci. Res., 16, 6778 .

[8] Jusakul A., Yongvanit P., Loilome W., Namwat N., Kuver R., (2011). Mechanisms of oxysterol-induced carcinogenesis. Lipids in Health and Disease, 10:44,1-8.

[9] Levy D.; J. L. M. Ruiz; A. T. Celestino;S. F. Silva ; A. K. Ferreira ;C. Isaac , S. P. Bydlowski ,( 2014). Short-term effects of 7-ketocholesterol on human adipose tissue mesenchymal stem cells in vitro. Biochemical and Biophysical Research Communications ,446, 720-725.

[10] Guenther M., ( 1961). The essential oils, Vol. III, IV, 4th Ed. D Van Nostrand Company, Inc. Princeton, New Jersy. Tornto, New York, London.

[11] Zahra Salemi and Pooya, Samaneh Kamali (2012). Toxicity of Margarine on liver Enzymes (Aspartate amino transferas and Alanine amino transferase) in Rats. Iranian Journal of Toxicology. 6 ( 17 ) : 655-659. 
[12] Hegested, D.M. ; Mills, R.C. ; Elvehijem, C.A. and Hart, F.B., (1941). Choline in the nutrition of check. J. Biol. Chem., 138: 459.

[13] Camplell , T.A. , (1961). Methodology of protein evaluation. RAG. Nutr. Document R.101 adds. 37, June Melting, New York.

[14] Ali H., A. F. M. T. Rahman, S. Islam, Al Mamun, Shaheda Z., A. H. M. Khurshid A., Aziz A., Mamunur R., (2014). Combined Therapy of Pioglitazone and Atorvastatin Alleviate Diabetes in Rats More Effectively than That of Mono Therapy. Pharmacology \& Pharmacy, 5, 504-513.

[15] Trinder, P. (1969). Determination of glucose in blood using glucose oxidase with an altemative oxygen acceptor. Am. Clin. Biochem., 6:24-27.

[16] Waston, D.A., (1960): Simple method for the determination of serum cholesterol. Clin. Chem. Acta., 5:589-596.

[17] Assmann, G., (1979). A fully enzymatic colorimetric determination of HDL-cholesterol in the serum. Internist, 20: 559-565.

[18] Wieland, H. and Seidel, D. , (1983): A fully enzymatic colorimetric determination of HDL-cholesterol in the serum. J. Nutr., 109: 760 - 766.

[19] Wallach, J., (1992): Interpretation of Diagnostic Tests. A synopsis of aboratory medicine, $5^{\text {th } \mathrm{Ed}}$. A little brown hand book, Boston.

[20] Fossati, P. and Prencipe, L., (1982): The determination of triglycerdes using enzymatic methods. Clin. Chem., 28: 2077 -2081 .

[21] Kikuchi, H. H.; Onodera, N.; Mastubara, S.; Yasuda, E.; Chonan, O.; Takahashi, R. and Ishikawa, F. (1998).Effects of soy milk and bifidobacterium fermented soy milk on lipid metabolism in aged ovariectomized rats. Bioscience, Biotechnology and Biochemistry, 62, (9): 1688-1692.

[22] Bergmeyer, H. U. and Harder, M., (1986). A colorimeteric method of determination of serum glutamic oxaloacetic and glutamic pyruvic transaminase. Clin. Biochem., 24: 28 - 34.

[23] Varley, H. ; Gewenlock, A. and Bell, M., (1980): Practical Clinical Biochemistry. vol. 1. 5th ${ }^{\text {ed., }}$ pp. 741, 897. London: William Heinemen Medical. Books, Ltd.

[24] Henry, R. J. , (1974). Clinical Chemistry, Principles and Technichs, $2{ }^{\text {nd }}$ Edition, Harper and Raw, p. 525.

[25] ] Fawcett, J. K. and Scott, J. E. ,(1960). Enzymatic colorimetric method for determination urea in serum, plasma and urine. J. Clin. Path., 13,156-162.

[26] Caraway, W. T. (1955). Determination of uric acid in serum by a carbonate method. American Journal of Clinical Pathology 25: $840-845$.

[27] Meltzer, H.M. ; Folmer, M.; Wang, S. ; Lie, Q. ; Maage, A. and Mundal, H.H., (1997). Supplementary selenium influences the response to fatty acid induced oxidative stress in humans. Biological Trace Element Research, 60: 51-67.

[28] Ellman, G.L., (1959). Tissue sulfhydrl groups. Archieves of Biochem. and Biophys., 82: 70-77.

[29] Rotruck. J.J.; Pope, A. L.; Ganther, H.E. and Swanson, A.B., (1973). Selenium: biochemical role as a component of glutathione peroxidase. Science, 179: 588-590.
[30] Nishikimi ,M.; Roa,N.A. and Yog,K., (1972). The occurrence of superoxide anion in the reaction of reduced phenazine methosulphate and molecular oxygen. Biochem.Bioph. Res. Common., 46: 849-854 .

[31] Aebi H.,(1984).Catalase in vitro. Methods Enzymol .,105:121136.

[32] Mafouz, M.M. and Kummerow, F.A. (2000). Cholesterol-rich diets have different effects on lipid peroxidation, cholesterol oxides, and antioxidant enzymes in rats and rabbits. J. Nutri. Biochem., 11: 293- 302.

[33] Miyajima, H.; Adachi, J.; Kohno, S.; Takahashi, Y.; Ueno, Y. and Naito, T. (2001).Increased oxysterols associated with iron accumulation in the brains and visceral organs of acaeruloplasminaemia patients. J. Med; 94: 417- 422.

[34] Yoon, B.I.; Choi, Y.K. ; Kim, D.Y.; Hyun, B.H.; Joo, K.H.; Rim, H.J. and Lee, J.H. (2001): Infectivity and pathological changes in murine clonorchiasis: Comparison in immunocompetent and immunodeficient mice. J. Vet. Med. Sci., 63(4): 421-425.

[35] Snedecor, G.W. and Cochran, W.G. (1980). Statistical methods. $7^{\text {th Ed., }}$ p. 420. Iowa Stat. Univ. Press, Ames, Iowa, USA.

[36] Hsu, T.C., Y.C Chen, C. C. Tsai, J.H., Wu, S.L Li and B.S. Tzang (2010): Protective effect of taurin against hepatic abnormality in NZB/W F1 mice fed a hypercholesterolemia diet. Food Chem.; 119: 62-68.

[37] Monira A. A., Nermin M. E. and Hamdy T., (2012). The Protective Role of Rosemary (Rosmarinus officinalis) in Lead Acetate Induced Toxicity in Rats. Journal of Applied Sciences Research, 8(6): 3071-3082.

[38] Rezq, A. A. and El-Khamisy A. E., (2011). Hypolipideimic and Hypocholestermic Effect of Pine Nuts in Rats Fed High Fat, Cholesterol-Diet. World Applied Sciences Journal 15 (12): 1667-1677.

[39] Sheyla, L.M.; H. De Paula1; L.P. Maria, C. Rinaldo; E. Santos and L. Deoclécio (2005). Dietary models for inducing hypercholesterolemia in rats. Brazilian Archives of Biology and Tech.; 48: P.203-209.

[40] Manal, A. H.; Soha, H. A. and Ashraf, A. A., (2012). Effect of Water Extract Prepared from Green Tea, Black Tea and Cinnamon on Obese Rats Suffering from Diabetes. World Applied Sciences Journal 20 (7): 976-987.

[41] Uthandi A. and Ramasamy K. (2011). Hepatoprotective activity of sesame meal on high fat fed wistar rats. International Journal of Pharma Sciences and Research,Vol.2(12),205-211.

[42] Puskas, L.G., Z.B. Nagy, Z. Giricz, A. Onody, C. Csonka, and K. Kitajka, (2004). Cholesterol diet-induced hyperlipidemia influences gene expression pattern of rat hearts: a DNA microarray study, FEBS Lett.; 562: P.99-104.

[43] Norazmir, M.N. and Ayub, M.Y.(2010). Beneficial LipidLowering Effects of Pink Guava Puree in High Fat Diet Induced-Obese Rats. Mal J Nutr 16(1): 171 - 185.

[44] Labban L.; U. E. Mustafa and Y. M. Ibrahim,(2014). The Effects of Rosemary (Rosmarinus officinalis) Leaves Powder on Glucose Level, Lipid Profile and Lipid Perodoxation. International Journal of Clinical Medicine, 5, 297-304. 
[45] Jaiswal P., Pradeep Kumar, Vinay K Singh, Dinesh K Singh,(2009). Biological Effects of Myristica fragrans. ARBS Annu Rev Biomed Sci .,11:21-29.

[46] Shafaeizadeh, S.; J. Jalal; Akbare O. A.; A. Leila; R. Roghayeh; Narges K. ; Negar R. A. T., (2011). The effect of consuming oxidized oil supplemented with fiber on lipid profiles in rat model. J Res Med Sci., 16(12): 1541-1549.

[47] Kareem M. A.; G. S. Krushna; S. A. Hussain and K. L. Devi ,(2009).Effect of Aqueous Extract of Nutmeg on Hyperglycaemia, Hyperlipidaemia and Cardiac Histology Associated with Isoproterenol-induced Myocardial Infarction in Rats. Tropical Journal of Pharmaceutical Research, 8 (4): 337-344.

[48] Mohammadi, A. and Oshaghi, E. (2014): Effect of garlic on lipid profile and expression of LXR alpha in intestine and liver of hypercholesterolemic mice. Journal of Diabetes \& Metabolic Disorders; 13:20 .

[49] Vestergaard, M. C. Yoda, T. Hamada, T., Akazawa, Y.,Yoshida, Y. and Takagi, M. (2011). The effect of oxycholesterols on thermo-induced membrane dynamics. Biochimica et Biophysica Acta, 1808 : 2245-2251.

[50] Szuchman, A., Aviram, M., Musa, R., Khatib, S., Vaya, J. (2008). Characterization of oxidative stress in blood from diabetic vs hypercholesterolaemic patients, using a novel synthesized marker. Biomarkers, 13: 119-131.

[51] Seet, R.C.S., Lee, C.-Y.J., Lim, E.C.H., Tan, J.J.H., Quek, A.M.L., Chong, W.-L., Looi, W.-F., Huang, S.-H., Wang, H., Chan, Y.-H., Halliwell, B. (2010). Oxidative damage in Parkinson disease: measurement using accurate biomarkers. Free Radical Biol. Med., 48: 560-566.

[52] Macfarlane, I. ;Bomford, A. and Sherwood, R.A. (2000).Liver diseases and Laboratory Medicine.ACB Ventures Publications London.

[53] Dauqan E., M.A. ;A. Abdullah and H. A. Sani (2012).Lipid profile and antioxidant enzymes innormal and stressed rat fed with palm olein. American Journal of Applied Sciences, 9 (7): 1071-1078.

[54] Cui , B.; L. Su; L. XiaoJun; W.Jun; L. ShuHong; W. QiBo and S. P. Li ,(2011). Effects of Lycium Barbarum Aqueous and Ethanol Extracts on High-Fat-Diet Induced Oxidative Stress in Rat Liver Tissue. Molecules, 16, 9116-9128.

[55] Sulzle, A., Hirch, F. and Eder, K. (2004). Thermally oxidized dietary fat upregulates the expression of target genes of PPAR $\alpha$ in rat liver. J. Nutr., 134: 1375-1383.

[56] Stevens, L. A. ;Coresh, J. ; Greene, T. and Andrew, S. L. (2006). Assessing kidney function - measured and estimated glomerular filtration rate. N. England Journal of Medicine, 354:2473-2483.

[57] Bequette, B.J. and Sunny, N.E. (2005). Reading nitrogenexcretion in ruminants : the potential to increase urea recycling. Proc.of the 3 rd Mild- Atlantic Nutrition Confefence, Timonium, Maryland,22-24 March,123-133.

[58] De Castro, U.; S.R. Silva; M. Lima;W. Campagnole-Santos, M. and Alzamora A. (2013). Age-dependent effect of highfructose and high-fat diets on lipid metabolism and lipid accumulation in liver and kidney of rats. Lipids in Health and Disease; 12:136.

[59] Khan, N. and H. Mukhtar, (2007). Tea polypohenols for health promotion . Life Sci., 81: 519-533.

[60] Amin K. A.; Galaly S. R.; Hozayen W. G. and Ramadan S. M. (2014). Effects of Orlistat and Herbal Mixture Extract on Renal Function and Oxidative Stress Biomarkers in a Rat Model of High Fat Diet. International Journal of Biochemistry Research \& Review,4 (2): 173-192.

[61] Hamzaa R. G., A. N. El Shahat and H.M.S. Mekawey,(2012). Modulating Efficiency of $\gamma$-Irradiated Rosemary in Improving the Hepatic Antioxidant Status of Ethanol Administrated Rats. Biochem Anal Biochem , 1, 1-8. 